\title{
Overexpression of IL-17RC associated with ocular sarcoidosis
}

\author{
Wenting Wu'1,2,3, Ming Jin³, Yujuan Wang ${ }^{1,4}$, Baoying Liu', Defen Shen ${ }^{1}$, Ping Chen ${ }^{1}$, Susan Hannes ${ }^{1}$, Zhiyu Li ${ }^{1}$, \\ Sima Hirani ${ }^{1}$, Shayma Jawad', UNITE Human Ocular Inflammation Consortium, H Nida Sen ${ }^{1}$, Chi-Chao Chan ${ }^{1}$, \\ Robert B Nussenblatt ${ }^{1 *}$ and Lai Wei ${ }^{1,4^{*}}$
}

\begin{abstract}
Background: Sarcoidosis is a chronic inflammatory disease with a systemic granulomatous disorder affecting multiple organs including the eye. Both $\mathrm{CD}^{+} \mathrm{T}$ cell and macrophage have been linked to the pathogenesis of the disease.

Methods: The expression of IL-17RC was measured using FACS,immunohistochemistry and real-time PCR. Serum level of IL-17 was detected using ELISA.

Results: An elevated expression of IL-17RC on CD8 ${ }^{+} \mathrm{T}$ cells in peripheral blood was found in patients with ocular sarcoidosis as compared to healthy controls. Interestingly, we found a significant increase in the serum level of IL-17 in patients with ocular sarcoidosis as compared to healthy controls, which may be responsible for the induction of IL-17RC on $\mathrm{CD}^{+}$cells. In addition, IL-17RC appeared only in the retinal tissue of the patient with clinically active sarcoidosis.
\end{abstract}

Conclusions: Our results suggested a potential involvement of $\mathrm{IL}-17 \mathrm{RC} \mathrm{C}^{+} \mathrm{CD} 8^{+} \mathrm{T}$ cells in pathogenesis of ocular sarcoidosis.

Keywords: Ocular sarcoidosis, IL-17RC, CD8

\section{Background}

Sarcoidosis is a systemic granulomatous disorder affecting multiple organs. Chronic inflammation occurs predominantly in the lung. In addition, lymph node, gastrointestinal tract, skin, nervous system, liver, spleen, heart, kidney, and muscle can also be affected. Ocular involvement is found in $25-50 \%$ patients with sarcoidosis and can be the first clinical manifestation of the disease according to several American and European studies $[1,2]$. However, ocular involvement may be found in up to $89 \%$ of Japanese patients with systemic sarcoidosis, suggesting a potential racial difference of its clinical presentation. Ocular sarcoidosis can occur in the absence of other systemic manifestations. Although the diagnosis of sarcoidosis can be confirmed by biopsy of the skin, conjunctiva, peripheral lymph nodes, or lung, the etiology of sarcoid granulomas is unknown [1].

\footnotetext{
*Correspondence: drbob@nei.nih.gov; weil9@mail.sysu.edu.cn

'Laboratory of Immunology, National Eye Institute, National Institutes of Health, Bethesda, MD 20892, USA

${ }^{4}$ State Key Laboratory of Ophthalmology, Zhongshan Ophthalmic Center, Sun Yat-sen University, Guangzhou, China

Full list of author information is available at the end of the article
}

Recent studies suggest sarcoidosis susceptibility is dependent on both genetic and environmental risk factors [3]. All races can suffer from sarcoidosis. Aggregation among certain racial/ethnic groups [4], as well as increased concordance among monozygotic twins [5] both strongly support the probability of a genetic susceptibility to sarcoidosis. Recent case-control genetic studies and genome-wide association studies (GWAS) identified multiple single nucleotide polymorphisms (SNPs) that may be associated with sarcoidosis. These include polymorphisms within coding regions of $H L A$ $D R B 1$ and $H L A-D Q B 1, C A R D 15$ (caspase recruitment domain family member 15)/NOD2 (nucleotide-binding oligomerization domain containing 2), BTNL2 (butyrophilin-like protein 2), ANXA11 (annexin A11), RAB23 (RAB23, member RAS oncogene family), and $C F H$ (complement factor H) [6-14]. Moreover, exposure to musty odors and insecticides [15], as well as infectious agents including Propionibacterium acnes and Mycobacterium tuberculosis [16-18] found within sarcoid granulomas have been proposed as important environmental and occupational risk factors for sarcoidosis. Therefore, 
it is postulated that sarcoidosis is a multifactorial disease triggered by environmental and infectious agents in genetically susceptible individuals. However, it is unclear whether the different clinical manifestations presented in sarcoidosis patients are due to the unique etiology. For example, no clear genetic and environmental risk has been identified for ocular sarcoidosis yet. Importantly, current therapeutic strategies for sarcoidosis (such as corticosteroids, methotrexate/azathioprine/mycophenolate mofetil, and anti-TNF $\alpha$ treatment) were not designed according to any of the recently identified genetic and environmental risk factors.

Although the precise cause of inflammation in sarcoidosis remains an enigma, it is well-established that $\mathrm{CD} 4^{+}$ $\mathrm{T}$ helper cells and macrophages play critical roles during granuloma formation [19]. In addition to $\mathrm{CD} 4^{+} \mathrm{T}$ cells, $\mathrm{CD}^{+} \mathrm{T}$ cells have also been found in granulomas and BAF $[20,21]$, while its role in the pathogenesis of sarcoidosis is unclear. Locally and systemically activated macrophages release cytokines and chemokines such as IL-1 $\beta$, IL-6, IL-23, IL-12, IL-18, and CCL20, leading to the recruitment of IL-17 producing T helper 17 (Th17) cells to granulomas [22-25]. IL-17 is physiologically critical during host defense against bacterial, mycobacterial, and fungal infections [26]. However, IL-17 producing Th17 cells have been the leading cause of pathological inflammation in many diseases such as multiple sclerosis and rheumatoid arthritis [27]. Recent studies have found a predominant increase of IL- $17 \mathrm{~A}^{+} \mathrm{CD} 4^{+}$memory $\mathrm{T}$ cells in the peripheral blood and bronchoalveolar lavages of pulmonary sarcoidosis patients [22,24], strongly suggesting (Th17) cells may play an important role in the pathogenesis of sarcoidosis.

Our previous study has suggested an elevated IL-17RC expression on several types of cells in the peripheral blood and retinal tissues from patients with Age-related Macular Degeneration [28]. Therefore, in this study, we explored whether the expression of IL-17RC was changed in ocular sarcoidosis patients.

\section{Methods}

\section{Patients}

All protocols were approved by institutional review boards, and written informed consents were provided by the patients to the National Institutes of Health. The patient information including disease activity and medications was listed in Table 1. All patients present ocular manifestations. 10 of these 13 patients were biopsy proven; 3 of them were with active disease when blood samples were drawn; 4 of these 13 patients had sarcoid manifestations involving in organs other than the eye. The majority of these patients were on medications (listed in Table 1).
Table 1 Patient information

\begin{tabular}{|c|c|c|}
\hline & $\begin{array}{c}\text { Sarcoidosis } \\
\text { (Total 13) }\end{array}$ & $\begin{array}{c}\text { Control } \\
\text { (Total 18) }\end{array}$ \\
\hline \multicolumn{3}{|l|}{ General information } \\
\hline Gender (M/F) & $5 / 8$ & $13 / 5$ \\
\hline Ave. Age & 44 & 43 \\
\hline Race $\left(\mathrm{AA} / \mathrm{C} / \mathrm{H}^{*}\right)$ & $11 / 2 / 1$ & $18 / 0$ \\
\hline Ocular sarcoid & $13(100 \%)$ & - \\
\hline Neuro/Pulmonary/Joint Sarcoid & $1(8 \%) / 2(15 \%) / 1(8 \%)$ & - \\
\hline Active disease & $3(23 \%)$ & - \\
\hline Biopsy proven & $10(77 \%)$ & - \\
\hline \multicolumn{3}{|l|}{ Medication } \\
\hline Corticosteroid ${ }^{* *}$ & $10(77 \%)$ & - \\
\hline Immunosuppressive agent ${ }^{* * *}$ & $7(54 \%)$ & - \\
\hline Opioid & $4(31 \%)$ & - \\
\hline Hypertension drug & $3(23 \%)$ & - \\
\hline Heart disease drug & $3(23 \%)$ & - \\
\hline Diabetic Medication & $4(31 \%)$ & - \\
\hline Calcium & $4(31 \%)$ & - \\
\hline
\end{tabular}

\section{Detection of cell surface molecules by flow cytometry}

Whole blood, collected in sodium-heparin vacutainers (BD, CA), from patients or healthy volunteers was first subjected to red blood cell lysis using ACK lysis buffer (Quality Biological Inc, MD). Cells were then incubated in sterile PBS supplemented with $2 \%$ FCS and fluorochromeconjugated antibodies against CD3, CD4, CD8, CD14, CD19, CD56 (all from BD, CA) and IL-17RC (FAB22691A) and mouse- $\operatorname{IgG}_{2 B}$ isotype control (both from $R \& D, M N$ ), for 30 minutes at room temperature in the dark. Cells were washed three times and analysed on a MACSQuant flow cytometer (Miltenyi Biotec, Germany). All flow cytometry data were analysed using FlowJo 7.6 (Treestar, OR).

\section{ELISA}

Sera from sarcoidosis patients and healthy controls were centrifuged at $1400 \mathrm{rpm}$ for $15 \mathrm{~min}$ after $30 \mathrm{~min}$ of clotting and were stored at $-80^{\circ} \mathrm{C}$, followed by detection of IL-17A using the Human IL-17 Quantikine ELISA Kit (R\&D Systems, Minneapolis, MN) according to the manufacture's protocol.

\section{Cell culture}

$\mathrm{CD}^{+} \mathrm{T}$ cells were first isolated from peripheral blood of healthy controls or Sarcoidosis patients using EasySep Human CD8 Positive Selection Kit (StemCell Technologies, Canada). The cells were then cultured in RPMI-1640 medium supplemented with $10 \%$ fetal bovine serum (FBS), $2 \mathrm{mM}$ L-glutamine, 1X penicillin-streptomycin 
antibiotics (Invitrogen, CA), and stimulated by platebound anti-CD3 $(5 \mathrm{ng} / \mathrm{ml})$ and anti-CD28 $(2 \mathrm{ng} / \mathrm{ml})$ antibodies (both from eBioscience, $\mathrm{CA}$ ), with or without IL-17A (100 ng/ml) for 3 days.

\section{Immunohistochemistry}

Immunohistochemistry was performed as previously described [28]. Briefly, the citrate retrieval and avidin-biotincomplex immunoperoxidase technique was utilized on the unstained, de-paraffinized slides of two eyes from two patients with clinically active or quiet sarcoidosis. The primary antibody was rabbit anti-human IL-17RC polyclonal antibody (sc-99937) (Santa Cruz Biotechnology, CA) or control rabbit IgG. The secondary antibody was biotinconjugated goat anti-rabbit IgG (Vector Laboratories, Burlingame, CA). The substrate was avidin-biotinperoxidase complex (Vector Laboratories, Burlingame, $\mathrm{CA}$ ), and the chromogen was diaminobenzidine and nickel sulfate. The positive reaction will result in the production of a brown-blackish color.

\section{Microdissection and RT-PCR}

Microdissection of retinal tissues and RT-PCR assays for IL17RC expression were conducted as previously described [27]. Briefly, retinal tissues with either granulomatous inflammation (inflammatory) or non-inflammatory (normal) areas were microdissected. Total RNA was isolated using the Paradise RNA isolation kit (Applied Biosystems, CA). SYBR Green (Qiagen) primers were used for human IL17RC detection. All data were normalized to the beta-actin mRNA level. Expression fold-change was calculated by $2^{-\Delta \Delta C T}$.

\section{Statistical analysis}

Statistical analysis was performed using GraphPad Prism 5.0 software (GraphPad, CA). The Mann-Whitney test was used to compare differences between two groups and the significance level was set at $\mathrm{P}<0.05$.

\section{Results}

Elevated expression of IL-17RC on CD8 ${ }^{+} \mathrm{T}$ cells in peripheral blood of patients with ocular sarcoidosis

Our previous study identified a hypomethylated IL17RC promoter and elevated expression of IL17RC on CD14 ${ }^{+}$ monocytes in the peripheral blood of patients with agerelated macular degeneration [28]. Sarcoidosis has been suggested as a Th17 disease [19] and IL17RC is critical in mediating IL-17 induced tissue damage [29]. Therefore, we first tested whether the expression of IL-17RC was increased on PBMCs from patients with ocular sarcoidosis. FACS analysis of cell surface IL-17RC expression and markers identifying several major types of cells among PBMCs were performed. Intriguingly, the frequency of IL-17RC ${ }^{+}$cells among $\mathrm{CD}^{+} \mathrm{CD} 4^{+}$helper $\mathrm{T}$ cells, CD $14^{+}$monocytes, CD19 ${ }^{+} \mathrm{B}$ cells, and $\mathrm{CD} 56^{+} \mathrm{NK}$ cells was similar between healthy controls and ocular sarcoidosis patients (Figure 1). Importantly, we found that IL-17RC expression was significantly elevated only in $\mathrm{CD}^{+} \mathrm{T}$ cells in sarcoidosis patients as compared to healthy controls (Figure 2), suggesting a potential role the $\mathrm{IL}-17 \mathrm{RC}^{+} \mathrm{CD} 8^{+} \mathrm{T}$ cells may play in the pathogenesis of ocular sarcoidosis.

\section{Induction of IL-17RC expression by IL-17A in activated $\mathrm{CD}^{+} \mathrm{T}$ cells}

Very few cells were found to express cell-surface IL$17 \mathrm{RC}$ in the peripheral blood of healthy volunteers. It is unclear how IL-17RC was induced in $\mathrm{CD}^{+} \mathrm{T}$ cells in sarcoidosis patients. Our previous study suggested that IL-17, the ligand of IL-17RC, can induce IL-17RC expression in human monocyte and retinal pigment epithelium (RPE) [28]. Importantly, we found significantly elevated levels of IL-17 in the serum of patients with ocular sarcoidosis (Figure 3A). Therefore, we next examined whether IL-17 can induce the expression of IL17RC on $\mathrm{CD}^{+} \mathrm{T}$ cells. $\mathrm{CD} 8^{+} \mathrm{T}$ cells were isolated from peripheral blood of healthy controls or Sarcoidosis patients and stimulated by plate-bound anti-CD3 and antiCD28 antibodies with or without IL-17 for 3 days. As shown in Figure 3B, IL-17 significantly increased the expression of IL-17RC in the culture of peripheral $\mathrm{CD} 8^{+} \mathrm{T}$ cells from healthy controls. Consistent with the above results that an elevated expression of IL-17RC was found on $\mathrm{CD}^{+} \mathrm{T}$ cells in peripheral blood from patients with ocular sarcoidosis (Figure 2), more IL-17RC ${ }^{+}$cells were found in the cultures of $\mathrm{CD}^{+} \mathrm{T}$ cells, stimulated by plate-bound anti-CD3 and anti-CD28 antibodies for 3 days, from sarcoidosis patients than in the culture of $\mathrm{CD}^{+} \mathrm{T}$ cells from healthy controls (Figure 3B). However,

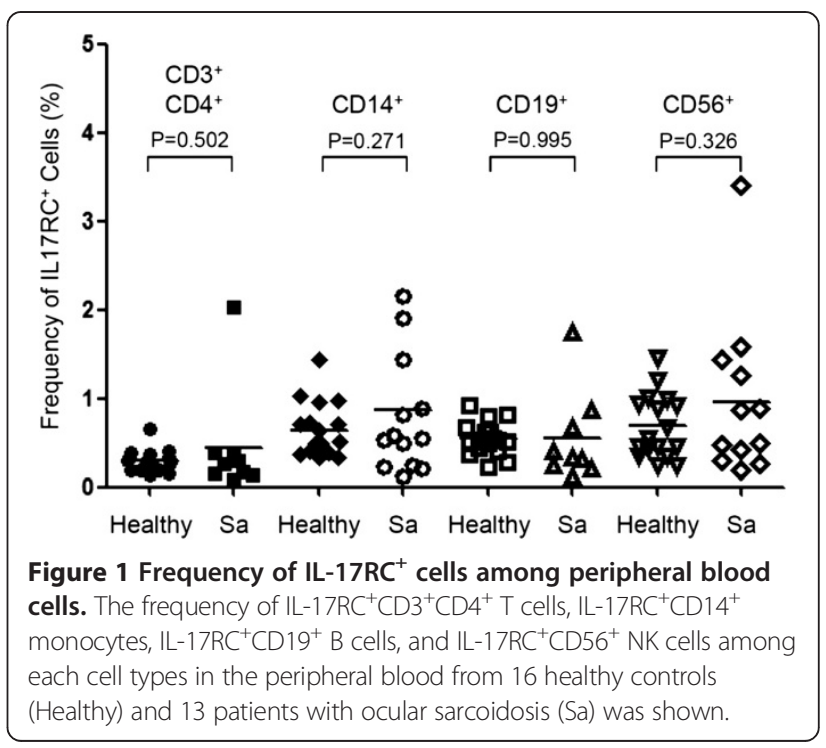




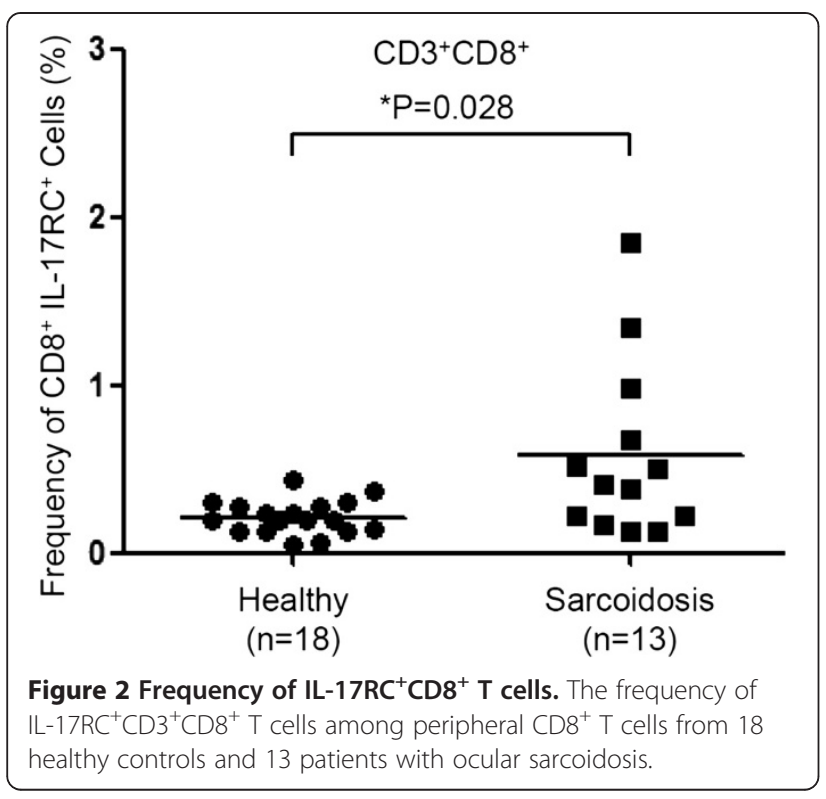

we only found a minimal induction of IL-17RC in response to IL-17 treatment on $\mathrm{CD}^{+} \mathrm{T}$ cells from sarcoidosis patients (Figure 3B).

\section{Elevated expression of IL-17RC in the eyes from patients with clinically active ocular sarcoidosis}

Previous studies have suggested that IL-17RC ${ }^{+}$cells may be able to migrate to the eye [28], we therefore tested whether IL-17RC ${ }^{+}$cells could be found in the retinal tissues of patients with either active or quiet ocular sarcoidosis. As shown in Figure 4A-D, immunohistochemistry assays demonstrated that IL-17RC expression in the retinal tissues of patients with clinically active ocular sarcoidosis (Figure 4A and B) was higher than its expression in the eye from patients with quiet disease clinically but small focal inflammation histopathologically (Figure $4 \mathrm{C}$ and D). In addition, in the eye with clinically active sarcoidosis, IL17RC RNA expression averaged at 108.1 fold higher in the retinal inflammatory lesion but only 14.2 fold higher in the normal retina compared to the normalization with beta-actin mRNA level. However, IL17RC expression was below the detectable level in both the inflammatory and normal retina of the eye with clinically quiet disease (Figure 4E). Taken together, these data suggest that the expression of IL-17RC may correlate with the clinical disease severity.

\section{Discussion}

Both Th1 and Th17 cells have been found to be crucial in leading to the formation of granulomas, the clinical hallmark of sarcoidosis [22]. An elevated level of IL-17 has been found in granulomas in the lung, BAF, as well as circulating $\mathrm{CD}^{+} \mathrm{T}$ cells in patients with pulmonary sarcoidosis $[24,30]$. In our study, we also found a significant increase in the serum level of IL-17 in patients with ocular sarcoidosis as compared to healthy controls. Therefore, IL-17 mediated chronic inflammation may be a leading cause of tissue pathology in sarcoidosis.

Our previous study suggests that IL-17 is able to upregulate the expression of its own receptor, IL-17RC, on multiple cell types including $\mathrm{CD} 14^{+}$monocytes and retinal pigment epithelium to amplify its biological effects [28]. In our current study, we also found that IL-17 can induce the expression of IL-17RC on peripheral $\mathrm{CD}^{+} \mathrm{T}$ cells. Therefore, the elevated expression of IL-17RC in the peripheral blood of patients with ocular sarcoidosis may be due to the effect of increased serum level of IL17 in these patients. However, as shown in Figure 1, the frequency of IL-17RC ${ }^{+}$monocytes and NK cells was also slightly increased, without a statistical significance probably due to the small sample size. Therefore, elevation in the expression of IL-17RC may not be $\mathrm{CD}^{+} \mathrm{T}$ cell specific. It could be a common response of multiple cell types in the peripheral blood due to the elevated level of IL-17. Importantly, we found sustained expression of IL$17 \mathrm{RC}$ protein and transcripts in the retinal tissue with granulomatous inflammation of clinically active but not quiet sarcoidosis patients. These results suggested that
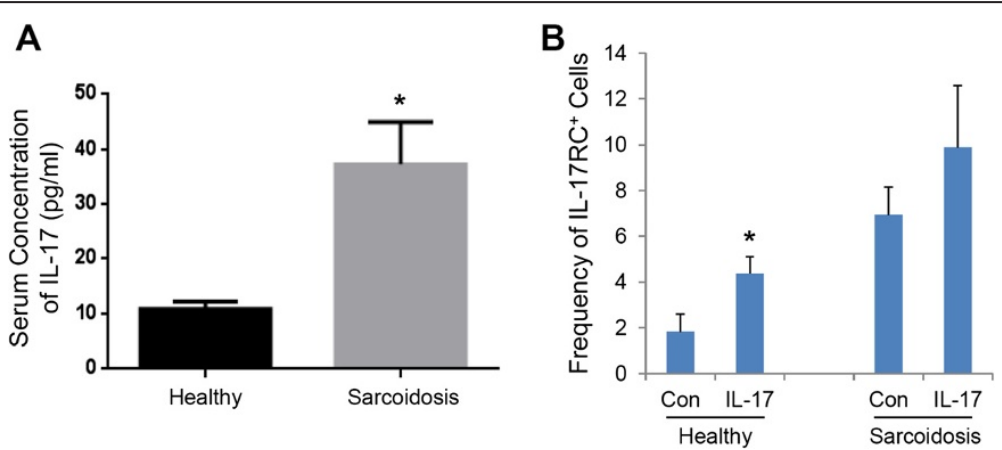

Figure 3 Induction of IL-17RC on CD8 ${ }^{+}$T cells. (A) Serum levels of IL-17 in 18 healthy controls and 13 patients with ocular sarcoidosis. (B) The frequency of $\mathrm{IL}-17 \mathrm{RC} C^{+}$in cultured $\mathrm{CD} 8^{+} \mathrm{T}$ cells treated with (IL-17) or without (Con) IL-17 from 4 healthy controls and 4 sarcoidosis patients. ${ }^{*} \mathrm{P}<0.05$. 


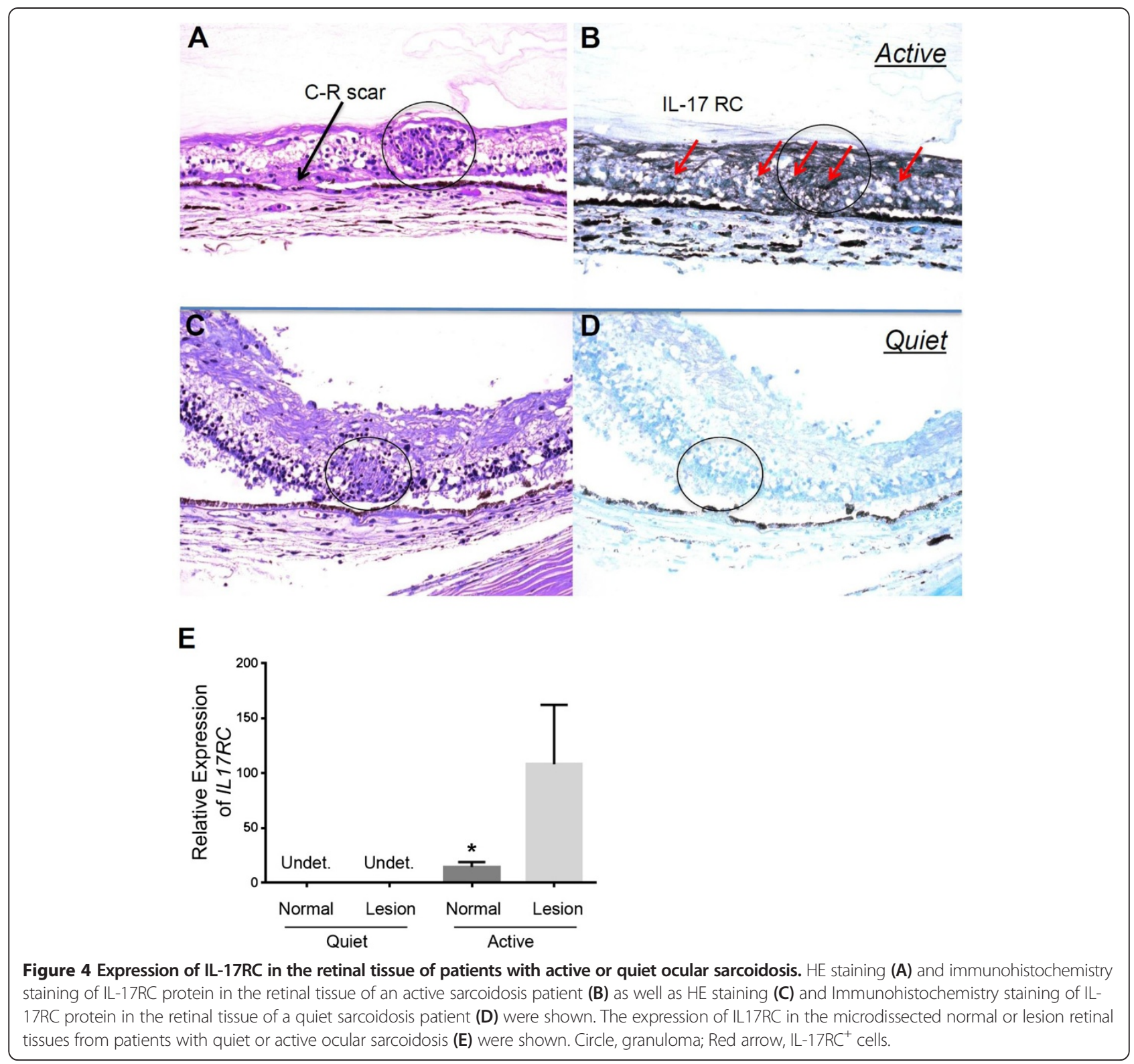

IL-17RC ${ }^{+}$cells may be able to migrate into the eye and facilitate the formation of granulomas.

$\mathrm{CD}^{+} \mathrm{T}$ cells, in addition to $\mathrm{CD} 4^{+} \mathrm{T}$ cells, have also been found in granulomas [21]. We have also reported that $10 \%$ of the lymphocytic infiltration was $\mathrm{CD}^{+} \mathrm{T}$ cells but these cells were rarely found within granulomas in an eye with clinically active sarcoidosis [31]. Candia et al. [32] as well as Zhou et al. [33] have also suggested a crucial role $\mathrm{CD}^{+} \mathrm{T}$ cells play in the pathogenesis of sarcoidosis. In this study, we found that the frequency of IL-17RC ${ }^{+} \mathrm{CD}^{+}$cells was increased in ocular sarcoidosis patients, which strongly suggests involvement of inflammatory $\mathrm{CD}^{+} \mathrm{T}$ cells in sarcoidosis. Many infectious pathogens have been found in granulomas in sarcoidosis patients. It would be interesting to investigate whether evidence of viral infection can be identified in or around granulomas given the potential involvement of $\mathrm{CD}^{+}$ $\mathrm{T}$ cells.

A low frequency of IL-17RC ${ }^{+}$cells in the whole blood was found on $\mathrm{CD}^{+} \mathrm{T}$ cells, not only in healthy controls but also in patients with ocular sarcoidosis. However, a significantly more IL-17RC ${ }^{+}$cells can be found in the cultures of $\mathrm{CD}^{+} \mathrm{T}$ cells stimulated by anti-CD3/antiCD28 antibodies as compared to the unstimulated whole blood test, suggesting that during active inflammation, IL-17RC ${ }^{+} \mathrm{CD}^{+} \mathrm{T}$ cells might be activated by local antigen in the eye, which might contribute to the formation of granulomas in sarcoidosis patients. 


\section{Conclusions}

Our results demonstrated an elevated expression of IL17RC on $\mathrm{CD}^{+} \mathrm{T}$ cells in patients with sarcoidosis, supporting a potential role of these $\mathrm{T}$ cells played in the pathogenesis of ocular sarcoidosis.

\section{Competing interests}

The authors declare that they have no competing interests.

\section{Authors' contributions}

LW and RBN conceived the study and drafted the manuscript. LW, MJ, HNS, CCC, and RBN participated in the study design. WW, YW, PC, BL, ZL, SH, and SJ carried out the experiments. All authors read and approved the final manuscript.

\section{Acknowledgements}

This study is supported by the intramural research program of NEI and NCCAM.

\section{Author details}

${ }^{1}$ Laboratory of Immunology, National Eye Institute, National Institutes of Health, Bethesda, MD 20892, USA. ${ }^{2}$ Beijing University of Chinese Medicine, Beijing, China. ${ }^{3}$ Department of Ophthalmology, China-Japan Friendship Hospital, Beijing, China. ${ }^{4}$ State Key Laboratory of Ophthalmology, Zhongshan Ophthalmic Center, Sun Yat-sen University, Guangzhou, China.

Received: 8 March 2014 Accepted: 14 May 2014

Published: 31 May 2014

\section{References}

1. Jamilloux Y, Kodjikian L, Broussolle C, Seve P: Sarcoidosis and uveitis. Autoimmun Rev 2014, doi:10.1016/j.autrev.2014.04.001.

2. Kawagoe T, Mizuki N: Sarcoidosis. Curr Opin Ophthalmol 2011, 22:502-507.

3. Culver DA, Newman LS, Kavuru MS: Gene-environment interactions in sarcoidosis: challenge and opportunity. Clin Dermatol 2007, 25:267-275.

4. Rybicki BA, Major M, Popovich J Jr, Maliarik MJ, lannuzzi MC: Racial differences in sarcoidosis incidence: a 5-year study in a health maintenance organization. Am J Epidemiol 1997, 145:234-241.

5. Sverrild A, Backer V, Kyvik KO, Kaprio J, Milman N, Svendsen CB, Thomsen SF: Heredity in sarcoidosis: a registry-based twin study. Thorax 2008, 63:894-896.

6. Hofmann S, Franke A, Fischer A, Jacobs G, Nothnagel M, Gaede KI, Schurmann M, Muller-Quernheim J, Krawczak M, Rosenstiel P, Schreiber S: Genome-wide association study identifies ANXA11 as a new susceptibility locus for sarcoidosis. Nat Genet 2008, 40:1103-1106.

7. Hofmann S, Fischer A, Till A, Muller-Quernheim J, Hasler R, Franke A, Gade Kl, Schaarschmidt H, Rosenstiel P, Nebel A, Schurmann M, Nothnagel M, Schreiber S: A genome-wide association study reveals evidence of association with sarcoidosis at 6p12.1. Eur Respir J 2011, 38:1127-1135.

8. Adrianto I, Lin CP, Hale JJ, Levin AM, Datta I, Parker R, Adler A, Kelly JA, Kaufman KM, Lessard CJ, Moser KL, Kimberly RP, Harley JB, lannuzzi MC, Rybicki BA, Montgomery CG: Genome-wide association study of African and European Americans implicates multiple shared and ethnic specific loci in sarcoidosis susceptibility. PLoS One 2012, 7:e43907.

9. Valentonyte R, Hampe J, Huse K, Rosenstiel P, Albrecht M, Stenzel A, Nagy M, Gaede KI, Franke A, Haesler R, Koch A, Lengauer T, Seegert D, Reiling N, Ehlers S, Schwinger E, Platzer M, Krawczak M, Muller-Quernheim J, Schurmann M, Schreiber S: Sarcoidosis is associated with a truncating splice site mutation in BTNL2. Nat Genet 2005, 37:357-364.

10. Rybicki BA, Walewski JL, Maliarik MJ, Kian H, lannuzzi MC: The BTNL2 gene and sarcoidosis susceptibility in African Americans and Whites. Am J Hum Genet 2005, 77:491-499.

11. Sato H, Woodhead FA, Ahmad T, Grutters JC, Spagnolo P, van den Bosch JM, Maier LA, Newman LS, Nagai S, Izumi T, Wells AU, du Bois RM, Welsh Kl: Sarcoidosis HLA class II genotyping distinguishes differences of clinical phenotype across ethnic groups. Hum Mol Genet 2010, 19:4100-4111.

12. Sato H, Williams HR, Spagnolo P, Abdallah A, Ahmad T, Orchard TR, Copley SJ, Desai SR, Wells AU, du Bois RM, Welsh KI: CARD15/NOD2 polymorphisms are associated with severe pulmonary sarcoidosis. Eur Respir J 2010, 35:324-330.

13. Grunewald J: Review: role of genetics in susceptibility and outcome of sarcoidosis. Semin Respir Crit Care Med 2010, 31:380-389.
14. Thompson IA, Liu B, Sen HN, Jiao X, Katamay R, Li Z, Hu M, Hejtmancik F, Nussenblatt RB: Association of complement factor $\mathrm{H}$ tyrosine 402 histidine genotype with posterior involvement in sarcoid-related uveitis. Am J Ophthalmol 2013, 155:1068-1074.e1061.

15. Newman LS, Rose CS, Bresnitz EA, Rossman MD, Barnard J, Frederick M, Terrin ML, Weinberger SE, Moller DR, McLennan G, Hunninghake G, DePalo L, Baughman RP, lannuzzi MC, Judson MA, Knatterud GL, Thompson BW, Teirstein AS, Yeager H Jr, Johns CJ, Rabin DL, Rybicki BA, Cherniack R: A case control etiologic study of sarcoidosis: environmental and occupational risk factors. Am J Respir Crit Care Med 2004, 170:1324-1330.

16. Eishi Y, Suga M, Ishige I, Kobayashi D, Yamada T, Takemura T, Takizawa T, Koike M, Kudoh S, Costabel U, Guzman J, Rizzato G, Gambacorta M, du Bois R, Nicholson AG, Sharma OP, Ando M: Quantitative analysis of mycobacterial and propionibacterial DNA in lymph nodes of Japanese and European patients with sarcoidosis. J Clin Microbiol 2002, 40:198-204.

17. Robinson LA, Smith P, Sengupta DJ, Prentice JL, Sandin RL: Molecular analysis of sarcoidosis lymph nodes for microorganisms: a case-control study with clinical correlates. BMJ Open 2013, 3:e004065.

18. Brownell I, Ramirez-Valle F, Sanchez M, Prystowsky S: Evidence for mycobacteria in sarcoidosis. Am J Respir Cell Mol Biol 2011, 45:899-905.

19. Broos CE, van Nimwegen M, Hoogsteden HC, Hendriks RW, Kool M, van den Blink B: Granuloma formation in pulmonary sarcoidosis. Front Immunol 2013, 4:437.

20. Heron M, Claessen AM, Grutters JC, van den Bosch JM: T-cell activation profiles in different granulomatous interstitial lung diseases-a role for CD8 + CD28(null) cells? Clin Exp Immunol 2010, 160:256-265.

21. Tondell A, Ro AD, Asberg A, Borset M, Moen T, Sue-Chu M: Activated CD8 T cells and NKT cells in BAL fluid improve diagnostic accuracy in sarcoidosis. Lung 2013, 192(1):133-40.

22. Grunewald J, Eklund A: Role of CD4+ T cells in sarcoidosis. Proc Am Thorac Soc 2007, 4:461-464

23. Dagur PK, Biancotto A, Wei L, Sen HN, Yao M, Strober W, Nussenblatt RB, McCoy JP Jr: MCAM-expressing CD4(+) T cells in peripheral blood secrete IL-17A and are significantly elevated in inflammatory autoimmune diseases. J Autoimmun 2011, 37:319-327.

24. Ten Berge B, Paats MS, Bergen IM, van den Blink B, Hoogsteden HC, Lambrecht BN, Hendriks RW, Kleinjan A: Increased IL-17A expression in granulomas and in circulating memory $T$ cells in sarcoidosis. Rheumatology (Oxford) 2012, 51:37-46.

25. Amadi-Obi A, Yu CR, Liu X, Mahdi RM, Clarke GL, Nussenblatt RB, Gery I, Lee YS, Egwuagu CE: TH17 cells contribute to uveitis and scleritis and are expanded by IL-2 and inhibited by IL-27/STAT1. Nat Med 2007, 13:711-718.

26. Curtis MM, Way SS: Interleukin-17 in host defence against bacterial, mycobacterial and fungal pathogens. Immunology 2009, 126:177-185.

27. Korn T, Bettelli E, Oukka M, Kuchroo VK: IL-17 and Th17 Cells. Annu Rev Immunol 2009, 27:485-517.

28. Wei L, Liu B, Tuo J, Shen D, Chen P, Li Z, Liu X, Ni J, Dagur P, Sen HN, Jawad S, Ling D, Park S, Chakrabarty S, Meyerle C, Agron E, Ferris FL 3rd, Chew EY, McCoy JP, Blum E, Francis PJ, Klein ML, Guymer RH, Baird PN, Chan CC, Nussenblatt RB: Hypomethylation of the IL17RC promoter associates with age-related macular degeneration. Cell Rep 2012, 2:1151-1158.

29. Hu Y, Ota N, Peng I, Refino CJ, Danilenko DM, Caplazi P, Ouyang W: IL-17RC is required for IL-17A- and IL-17F-dependent signaling and the pathogenesis of experimental autoimmune encephalomyelitis. J Immunol 2010, 184:4307-4316.

30. Urbankowski T, Hoser G, Domagala-Kulawik J: Th1/Th2/Th17related cytokines in the bronchoalveolar lavage fluid of patients with sarcoidosis: association with smoking. Pol Arch Med Wewn 2012, 122:320-325

31. Chan CC, Wetzig RP, Palestine AG, Kuwabara T, Nusenblatt RB: Immunohistopathology of ocular sarcoidosis. Report of a case and discussion of immunopathogenesis. Arch Ophthalmol 1987, 105:1398-1402.

32. Candia J, Maunu R, Driscoll M, Biancotto A, Dagur P, McCoy JP Jr, Sen HN, Wei L, Maritan A, Cao K, Nussenblatt RB, Banavar JR, Losert W: From cellular characteristics to disease diagnosis: uncovering phenotypes with supercells. PLoS Comput Biol 2013, 9:e1003215.

33. Zhou T, Zhang W, Sweiss NJ, Chen ES, Moller DR, Knox KS, Ma SF, Wade MS, Noth I, Machado RF, Garcia JG: Peripheral blood gene expression as a novel genomic biomarker in complicated sarcoidosis. PLoS One 2012, 7:e44818.

doi:10.1186/1479-5876-12-152

Cite this article as: Wu et al:: Overexpression of IL-17RC associated with ocular sarcoidosis. Journal of Translational Medicine 2014 12:152. 